WIDER Working Paper 2018/122

\title{
Risk and investment
}

Evidence from rural Vietnam

Carol Newman ${ }^{1}$ and Finn Tarp ${ }^{2}$

October 2018 
Abstract: This paper explores the impact of exposure to uninsured risks on the investment decisions of farmers. We distinguish between households' perceived exposure to uninsured risk, measured as past exposure to deviations in average rainfall levels, and the actual realization of shocks. We examine how households cope with the latter in terms of consumption smoothing and the depletion of assets. We also consider the interaction between past weather-risk exposure and the actual realization of weather shocks to ascertain the extent to which the investment strategies of risk-exposed households 'pay off' by buffering them in the face of actual shocks. We use panel data on rice farmers in Vietnam for the 2008-16 period and match this to annual rainfall data. Our results show that households that are exposed to risk invest more in unproductive assets to avoid the downside risk associated with exposure to flooding. This translates into lower income levels. The investment in these assets does not appear to pay off once actual risks are realized.

Keywords: risk, rainfall, weather shocks, investment, risk-coping, Vietnam

JEL classification: D14, D81, O12

Acknowledgements: This paper builds in parts on earlier work with Fiona Wainwright. We warmly acknowledge this collaboration. Our thanks also to Clíona Ní Mhógáin and Saoirse Mhathuna for their excellent research assistance.

1Department of Economics and Trinity Impact Evaluation Unit (TIME), Trinity College Dublin, Dublin, Ireland, corresponding author, email: cnewman@tcd.ie, ${ }^{2}$ UNU-WIDER, Helsinki, Finland and the Department of Economics and Development Economics Research Group (DERG), University of Copenhagen, Copenhagen, Denmark.

This study has been prepared within the UNU-WIDER project on 'Structural transformation and inclusive growth in Vietnam'.

Copyright (C) UNU-WIDER 2018

Information and requests: publications@wider.unu.edu

ISSN 1798-7237 ISBN 978-92-9256-564-0 https://doi.org/10.35188/UNU-WIDER/2018/564-0

Typescript prepared by Lesley Ellen.

The United Nations University World Institute for Development Economics Research provides economic analysis and policy advice with the aim of promoting sustainable and equitable development. The Institute began operations in 1985 in Helsinki, Finland, as the first research and training centre of the United Nations University. Today it is a unique blend of think tank, research institute, and UN agency — providing a range of services from policy advice to governments as well as freely available original research.

The Institute is funded through income from an endowment fund with additional contributions to its work programme from Finland, Sweden, and the United Kingdom as well as earmarked contributions for specific projects from a variety of donors.

Katajanokanlaituri 6 B, 00160 Helsinki, Finland

The views expressed in this paper are those of the author(s), and do not necessarily reflect the views of the Institute or the United Nations University, nor the programme/project donors. 
Exposure to risk remains a significant cause of poverty in less developed countries, where farming households face a high probability of income loss due to weather-related shocks. The ability of households to adapt to the prevalence of income risks and cope in the aftermath of the realization of such risks is an important determinant of welfare. In many rural settings risk-mitigation strategies are particularly difficult since credit and insurance markets are often not well developed. ${ }^{1}$ This is especially the case for farming households who face considerable downside risk associated with agricultural investments due to the potential for weather shocks to negatively affect output. This leads farmers to divert investment away from productive agricultural assets towards precautionary savings, either cash or through the accumulation of other liquid assets. ${ }^{2}$ Thus, uninsured production risk can have real consequences for agricultural productivity and income levels.

In this paper, we explore the impact of exposure to uninsured risks, measured as past exposure to deviations in average rainfall levels, on the investment decisions of farmers. Unlike other studies, we distinguish between households' perceived exposure to uninsured risk and the actual realization of shocks. We examine how households cope with the latter in terms of consumption smoothing and the depletion of assets. Our key point of departure is that we consider the interaction between past weather-risk exposure and the actual realization of weather shocks to ascertain the extent to which the investment strategies of risk-exposed households 'pay off' by buffering them in the face of actual shocks.

The context for our study is Viet Nam where weather-related risks are large and agriculture, in particular rice production, continues to play an important role in the economy for food security, rural employment, and exports. While rice cultivation requires a lot of water, the crop is very vulnerable to excessive flooding, and so weather variability poses a threat to the success of the crop. Viet Nam is ranked as one of South East Asia's most hazardous areas in relation to natural disasters such as cyclones, flooding, and droughts and is particularly vulnerable to climate change, with rainfall expected to increase by 8 per cent in the winter season by 2050 (World Bank 2011). Weather-related risk remains formally uninsurable in Viet Nam. In this setting, past exposure to deviations in rainfall will make uninsurable risks more salient for rice-producing farmers and so Viet Nam provides the ideal case for exploring the impact of uninsurable risks on asset accumulation, incomes, and food consumption.

We use the Viet Nam Access to Resources Household Survey (VARHS), a rich panel dataset from Viet Nam for the period 2008 to 2016 which was collected every two years, specifically to understand access to resources of rural households and their decision-making processes around the accumulation of these assets and the generation of income. The data cover 2,700 households over the eight-year period, and we select the sub-sample of rice-producing farmers (66 per cent) for our analysis. Our data include details on assets, agricultural production, incomes, food expenditure, and other household characteristics, in addition to self-reported exposure to weatherrelated shocks. We supplement these data with data on rainfall measured at the commune level.

\footnotetext{
${ }^{1}$ Cole et al. (2013) find, using a series of field experiments in India, that rainfall insurance is highly price sensitive. They also find that demand is constrained by a lack of trust and liquidity constraints. As a result, it is often not feasible for insurance providers to enter into these markets.

2 See, Alderman and Paxson (1992), Deaton (1991; 1992), Morduch (1995; 2004), Rosenzweig and Binswanger (1993), Udry (1994), and Zeldes (1989).
} 
We measure households' exposure to risk as past deviations (three-year lag) of rainfall from the long-term (six-year) average. We use a household fixed effects approach so that our identification comes from the within-household variation in past exposure to risk and the actual realization of shocks as reported by households in the data. Including household fixed effects controls for all time-invariant household-specific factors that could impact on both risk perceptions (such as risk aversion) and the outcomes of interest (asset accumulation, income, and food expenditure). The incidence of weather-related shocks is considered exogenous.

We approach our analysis in three steps. First, we estimate the impact of shocks on household income and food consumption and explore the ways households cope when exposed to shocks. Second, we examine the way in which long-term risk exposure impacts on the investment decisions of households and how that impacts on income and food consumption. In other words, controlling for other factors, including actual realizations of shocks, do farmers that have been exposed to greater weather variability in the past invest less in productive assets and more in nonproductive assets, and is there evidence that this reduces income and consumption levels? This allows us to separate out the short-term impact of shocks from the long-term impact of risk. Finally, we explore whether households with greater long-term risk exposure cope better in the event of the realization of a weather shock.

Understanding the link between uninsured risk and sub-optimal production decisions has been given much attention in the recent literature. Karlan et al. (2014) find that the provision of insurance to farmers in Northern Ghana leads to significantly larger agricultural investments and riskier production choices. Similarly, Cole et al. (2017) find that insurance provision leads farmers to shift their production towards higher-return but higher-risk cash crops in India. Elabed and Carter (2014) find similar results for cotton farming in Mali. Gloede (2015) uses survey data from Viet Nam and finds that shocks increase risk aversion and leave households more vulnerable to poverty. Jensen et al. (2017) find that households in Kenya covered by an index-based insurance product make more productivity investments, sell less livestock in times of financial distress, and experience increased income levels. Another form of insurance against weather risk that has been considered in the literature relates to the introduction of new technologies that eliminate the downside risk. Emerick et al. (2016) show that the adoption of a new technology that eliminates the downside risk associated with flooding changes the input choices of rice farmers with the effect of increasing productivity.

We contribute to this literature in a number of ways. First, we consider both long-term (riskmanagement) and short-term (risk-coping) strategies of households that are exposed to weather risk. Alderman and Paxson (1992) distinguish between risk-management strategies which involve adjusting the (perceived) riskiness of the income-generating process and risk-coping strategies which refer to the adjustments that households make to cope with income shocks. The previous literature cited above has focused on one or the other and has, generally, not considered them both simultaneously. In this paper, we explore both dimensions. Second, we explore the interaction between weather-risk exposure and the actual realization of weather shocks to ascertain whether the strategy of diverting assets away from productive agricultural assets to avoid the downside risk actually protects these households when that risk is eventually realized. To our knowledge, this is the first paper to explore this important interaction. Third, we provide new evidence of the impact of weather variability on the welfare of farmers in a setting that is particularly exposed and vulnerable to climate change.

Our results show that households cope with the realization of weather-related shocks by depleting their savings and borrowing. While they manage to smooth consumption, the incidence of a shock has a negative effect on their income levels. We find that households that are exposed to risk invest a greater proportion in unproductive assets and less in productive agricultural assets. This is 
consistent with a story where more risk-exposed households divert investment away from agriculture to avoid the downside risk associated with exposure to flooding. We also find, however, that the most risk-exposed households rely more on income from crops, and so it is not surprising that they have significantly lower overall household income levels. This diversion of resources does not appear to pay off in that the investment in these 'buffer' assets does not shield households from income losses once actual risks are eventually realized. Farmers are, in fact, hit in a more or less similar way to other households that did not engage in unproductive risk-mitigation strategies.

The rest of our paper is organized as follows. Section 2 describes our data, while Section 3 presents the empirical approach. Section 4 presents the results and Section 5 concludes.

\section{Data}

Our data come from VARHS for the period 2008-16. The data cover a representative sample of rural households in 12 provinces in North, South, and Central Viet Nam. These provinces cover a large proportion of the rice-growing area of Viet Nam, with a substantial number of households sampled in the poor upland provinces in the North West and Central Highlands. The data are collected every two years with the full panel comprising over 2,700 households. There are very low rates of attrition between rounds, and additional households were added to the panel to ensure that it continued to be representative. The data are collected using face-to-face interviews by a team of enumerators overseen by our collaborating partner, the Institute of Labor Science and Social Affairs (ILSSA). VARHS collects a broad range of detailed information about economic and social aspects of the lives of households in these rural provinces, including data on agricultural production, livelihoods, and financial aspects. The definition of each of the variables used in our analysis and summary statistics for each year are presented in Tables A1 to A4 of the Appendix.

We use the sub-sample of rice-producing farmers in VARHS, which account for approximately 65 per cent of the total sample. Details on the overall sample size and the size of the sub-sample in each round of the data are presented in Table 1. A key variable of interest for our analysis is the realization of weather-related income shocks. In the survey, households are asked whether in the previous two years they suffered from an unexpected loss due to floods, droughts, typhoons and other natural disasters, pest infestations, and crop diseases. The proportion of households in our sample exposed to such shocks in each year is also presented in Table 1. In 2008 over half of the households experienced such a shock. This declined consistently over the sample period with only 27 per cent of the sample reporting that they experienced such shocks in 2016. This decline may be due to a number of factors. It could be due to the fact that the households that experienced shocks in earlier rounds left rice farming, although this is unlikely to be the case given that only 27 per cent of households that switch out of rice production experienced a shock in the previous period. It could also be related to the fact that the data are self-reported and so perceptions about what an income shock actually is could have changed. Our assumption is that households accurately report the incidence of shocks and so the summary statistics reflect a true decline in the actual incidence of shocks over the period. This caveat, nonetheless, should be borne in mind when interpreting the results. 


\begin{tabular}{llccccc}
\hline & & 2008 & 2010 & 2012 & 2014 & 2016 \\
& & $\mathrm{n}=2,278$ & $\mathrm{n}=2,245$ & $\mathrm{n}=2,759$ & $\mathrm{n}=2,725$ & $\mathrm{n}=1,447$ \\
\hline \% Rice producers & & 72.26 & 69.98 & 65.64 & 63.67 & 58.94 \\
& & $\mathrm{n}=1,506$ & $\mathrm{n}=1,450$ & $\mathrm{n}=1,694$ & $\mathrm{n}=1,640$ & $\mathrm{n}=1,447$ \\
\hline Shock & Mean & 0.518 & 0.490 & 0.382 & 0.309 & 0.272 \\
Past dev. rainfall & Std. dev. & 0.500 & 0.500 & 0.486 & 0.462 & 0.445 \\
& Mean & 0.083 & 0.129 & 0.125 & 0.011 & 0.065 \\
Past mean rainfall & Std. dev. & 0.046 & 0.142 & 0.055 & 0.064 & 0.054 \\
& Mean & 7.497 & 7.544 & 7.398 & 7.533 & 7.504 \\
\hline
\end{tabular}

Source: Authors' own calculations based on VARHS.

We measure risk by the deviation of rainfall in the commune from the previous six-year average. A lag length of three is chosen as the measure of actual realized shocks is any shocks that occurred in the previous two years. This implies that in 2008 , for example, the risk proxy is the deviation of the level of rainfall experienced in 2005 from the average level of rainfall experienced between 2000 and $2005 .^{3}$ We also control for the level of rainfall lagged by three periods given that a certain level of rainfall is required for rice production. Rainfall data are extracted from the University of Delaware Global Precipitation Archive V4.01 (Willmott and Matsuura 2001). The data contain global historical estimates of rainfall for a grid of 0.5 by 0.5 degree of geographic coordinates, where the grid nodes are centred on 0.25 degrees. We extract the data for Viet Nam for the 2000 to 2014 period and match them to each commune in the VARHS dataset.

Table 1 reports summary statistics for both the past rainfall level (measured in logs) and the standard deviation. Over the sample period, the rainfall level increased slightly while the standard deviation increased between 2008 and 2012 but decreased slightly thereafter. This is consistent with the decline in the incidence of weather-related shocks in 2014 and 2016 recorded in the VARHS data.

In Table 2, we present the main summary statistics disaggregated by risk quantile, with lower quantiles representing lower levels of risk and the realization of weather shocks. The incidence of weather-related shocks does not appear to be correlated with past deviations in rainfall. This is somewhat surprising and suggests that the perceptions of households in relation to their exposure to risk may not align with the actual realization of those risks. Exposure to risk also does not appear to be systematically correlated with any of the outcome variables of interest (income, food expenditure, and assets) or the household level control variables. In contrast, households that experience a natural disaster have lower income levels, lower levels of assets, and more loans. They are also likely to have lower education and larger households, and are more likely to be classified as poor by the authorities. In sum, it appears from our data that exposure to risk is less related to observable characteristics than exposure to natural shocks.

\footnotetext{
${ }^{3}$ All our results are robust to the use of the fourth lag. Earlier lags are not well determined, suggesting that households' risk perceptions, based on memories of past rainfall incidences, do not stretch back more than four years.
} 
There are three steps to our empirical analysis. We first examine the extent to which experiencing a natural shock impacts on the income and consumption levels of the household. To examine this issue, we estimate equation (1):

$$
Y_{i t}=\beta S_{i t}+\delta Z_{i t}+\alpha_{i}+\tau_{t}+u_{i t}
$$

where, $Y_{i t}$ is the outcome of interest, $S_{i t}$ is an indicator variable for whether the household experienced an income shock, $Z_{i t}$ is a vector of time-varying control variables, $\alpha_{i}$ are household fixed effects, $\tau_{t}$ are time dummies, and $u_{i t}$ is a statistical noise term. The identification of the effect of natural shocks on outcomes comes from the within-household changes in the incidence of shocks. While we consider the incidence of shocks to be out of the households' control and so exogenous, the inclusion of household fixed effects ensures that all observable and unobservable time-invariant household-specific characteristics that could impact on both the outcome of interest and the probability that the household is exposed to a natural shock are controlled for. The rich set of time-varying controls included in $Z_{i t}$ further sharpens our identification by controlling also for observable time-varying household-specific factors.

We are also interested in the shock-coping mechanisms of households, particularly in relation to their financial assets and access to credit. As such, we also estimate equation (1) with changes in the value of different types of asset classes and the value of loans between rounds as outcomes.

The second step of our empirical analysis explores the extent to which past exposure to weatherrelated risks impacts on the level and types of assets that households accumulate, as has been found to be the case in much of the literature cited in the introduction. To explore this, we estimate equation (2):

$$
Y_{i t}=\gamma v_{i t}+\beta S_{i t}+\eta R_{i t}+\delta Z_{i t}+\alpha_{i}+\tau_{t}+u_{i t}
$$

where, $v_{i t}$ is our measure of past exposure to risk as discussed above, $R_{i t}$ is the level of rainfall in the commune three years prior to the survey round, and all the other variables are the same as for equation (1). In this case, the outcomes of interest are the total level of assets, the share of assets that are productive, and the share of assets that are unproductive. We also examine what past risk exposure means for household incomes and food expenditure using this specification. As for equation (1), the inclusion of household fixed effects means that our identification comes from the within-household variation in risk exposure over time. As such, we assume that households' perceptions of their exposure to risk are updated in each round of the data. ${ }^{4}$

The third and final step examines the extent to which exposure to past risk, and by extension the past investment decisions of farmers, buffers them against future income shocks. To examine this issue, we extend the specification in equation (2) to include an interaction term between past risk exposure and the incidence of natural shocks. This specification is given in equation (3):

$$
Y_{i t}=\theta v_{i t} \times S_{i t}+\gamma v_{i t}+\beta S_{i t}+\eta R_{i t}+\delta Z_{i t}+\alpha_{i}+\tau_{t}+u_{i t}
$$

\footnotetext{
${ }^{4}$ We have some evidence from our data to suggest that households do not remember deviations in rainfall that occurred more than four years previously, which makes a two-year updating of perceptions around exposure to uninsured risk a realistic assumption.
} 
In this case, the key outcomes are income and the change in the value of different categories of assets, while the parameter of interest is $\theta$, which will allow us to determine the extent to which past exposure to risk exacerbates or mitigates the impact of shocks.

\section{$4 \quad$ Results}

We begin by examining the impact of adverse income shocks on household level outcomes. We focus on household income and food expenditure. The results of the specification given in equation (1) are presented in Table 3. As revealed in column (1), exposure to adverse income shocks related to natural disasters leads to a loss in household income. Shocks, however, do not lead to lower levels of food expenditure (column 8). This suggests that households find some way to smooth consumption and is consistent with the main theoretical predictions in the literature on this issue (see Townsend 1994). While households manage to smooth their consumption, they still face a loss in income, highlighting the fact that they will generally face difficulties in coping with risk and that not all risk will be insured (Dercon 2002). The main source of income affected by income shocks is, perhaps unsurprisingly, crop income. Column 2 reveals that once households have experienced a natural shock, the proportion of income that they generate from crops falls by over 2 per cent. They compensate for this loss with an increase in the proportion of income generated through waged employment and through public transfers from the state. This does not, however, go far enough in making up for the overall loss to household income.

In Table 4, we explore the extent to which households deplete their assets in response to a natural shock. While there is no evidence that natural shocks lead to a change in the overall value of assets owned by the household, the composition of assets does change. Households deplete their stock of savings (column 5) but increase their stock of livestock and agricultural equipment (columns (3) and (4)). ${ }^{5}$ Livestock is often considered a buffer stock against shocks given that it is not (generally) impacted by weather events. ${ }^{6}$ Increased investment in agricultural equipment is likely due to the need to replace damaged farm equipment after the shock. To smooth consumption, and at the same time increase investment in livestock and farm equipment, households draw down savings and take out loans (column (8)). This suggests that in times of crisis households can rely on sources of credit, but it also suggests that during these times they become more indebted, which may be problematic if these funds are not put to productive uses.

\footnotetext{
${ }^{5}$ Wainwright and Newman (2011) examine the link between income shocks and households' risk-coping strategies for the Vietnamese case. Using earlier waves of the VARHS data (2008-10), they find that households smooth consumption by depleting liquid assets.

${ }^{6}$ Rosenzweig and Wolpin (1993) propose that in the absence of risk mitigation strategies as a result of incomplete credit markets, households will use livestock as a buffer against unexpected income losses and as such can be considered a form of self-insurance. Fafchamps et al. (1998) also find empirical evidence for the use of livestock as a partial buffer against shocks.
} 
Table 2: Summary statistics by risk quantile and realization of shocks

\begin{tabular}{|c|c|c|c|c|c|c|c|c|}
\hline & Risk quantile & $n=1,625$ & $\begin{array}{c}2 \\
n=1,640\end{array}$ & $\begin{array}{c}3 \\
\mathrm{n}=1,698\end{array}$ & $\begin{array}{c}4 \\
n=1,657\end{array}$ & $\begin{array}{c}5 \\
\mathrm{n}=1,447\end{array}$ & $\begin{array}{l}\text { No shock } \\
n=4,700\end{array}$ & $\begin{array}{c}\text { Shock } \\
\mathrm{n}=3,037\end{array}$ \\
\hline \multirow[t]{2}{*}{ Shock } & Mean & 0.396 & 0.438 & 0.441 & 0.364 & 0.288 & & \\
\hline & Std. dev. & 0.489 & 0.496 & 0.497 & 0.481 & 0.453 & & \\
\hline \multirow[t]{2}{*}{ Dev. past rainfall } & Mean & 0.022 & 0.060 & 0.088 & 0.127 & 0.234 & 0.102 & 0.105 \\
\hline & Std. dev. & 0.010 & 0.013 & 0.006 & 0.015 & 0.088 & 0.077 & 0.090 \\
\hline \multirow[t]{2}{*}{ Past mean rainfall } & Mean & 7.541 & 7.431 & 7.535 & 7.488 & 7.458 & 7.494 & 7.491 \\
\hline & Std. dev. & 0.281 & 0.152 & 0.203 & 0.251 & 0.121 & 0.218 & 0.221 \\
\hline \multirow[t]{2}{*}{ Household income (log) } & Mean & 10.939 & 10.908 & 10.771 & 10.893 & 11.140 & 11.023 & 10.749 \\
\hline & Std. dev. & 0.822 & 0.779 & 0.828 & 0.835 & 0.792 & 0.822 & 0.789 \\
\hline \multirow[t]{2}{*}{ Food expenditure (log) } & Mean & 7.268 & 7.165 & 7.096 & 7.255 & 7.308 & 7.258 & 7.139 \\
\hline & Std. dev. & 0.752 & 0.718 & 0.830 & 0.747 & 0.712 & 0.763 & 0.749 \\
\hline \multirow[t]{2}{*}{ Total assets (log) } & Mean & 11.749 & 11.869 & 11.449 & 11.626 & 12.167 & 11.909 & 11.485 \\
\hline & Std. dev. & 1.596 & 1.559 & 1.490 & 1.702 & 1.718 & 1.695 & 1.469 \\
\hline \multirow[t]{2}{*}{ Share productive } & Mean & 0.767 & 0.746 & 0.731 & 0.701 & 0.773 & 0.731 & 0.756 \\
\hline & Std. dev. & 0.259 & 0.278 & 0.253 & 0.284 & 0.283 & 0.290 & 0.240 \\
\hline \multirow[t]{2}{*}{ Share unproductive } & Mean & 0.233 & 0.254 & 0.269 & 0.299 & 0.227 & 0.269 & 0.244 \\
\hline & Std. dev. & 0.259 & 0.278 & 0.253 & 0.284 & 0.283 & 0.290 & 0.240 \\
\hline \multirow[t]{2}{*}{ Total loans (log) } & Mean & 3.607 & 4.110 & 3.980 & 4.272 & 5.241 & 3.833 & 4.701 \\
\hline & Std. dev. & 4.844 & 5.065 & 4.954 & 5.082 & 5.253 & 5.017 & 5.055 \\
\hline \multirow[t]{2}{*}{ Education per capita } & Mean & 8.664 & 8.195 & 7.947 & 8.965 & 8.883 & 8.815 & 8.020 \\
\hline & Std. dev. & 2.514 & 2.868 & 2.936 & 2.331 & 2.367 & 2.457 & 2.888 \\
\hline \multirow[t]{2}{*}{ Household size } & Mean & 4.390 & 4.621 & 4.696 & 4.280 & 4.477 & 4.352 & 4.716 \\
\hline & Std. dev. & 1.669 & 1.742 & 1.745 & 1.608 & 1.666 & 1.649 & 1.742 \\
\hline \multirow[t]{2}{*}{$\mathrm{Sex} \mathrm{HoH}$} & Mean & 0.790 & 0.851 & 0.861 & 0.795 & 0.804 & 0.803 & 0.850 \\
\hline & Std. dev. & 0.408 & 0.357 & 0.346 & 0.404 & 0.397 & 0.398 & 0.357 \\
\hline \multirow[t]{2}{*}{ Married $\mathrm{HoH}$} & Mean & 0.804 & 0.869 & 0.859 & 0.821 & 0.831 & 0.822 & 0.861 \\
\hline & Std. dev. & 0.397 & 0.338 & 0.348 & 0.384 & 0.375 & 0.382 & 0.346 \\
\hline \multirow[t]{2}{*}{ Age $\mathrm{HoH}$} & Mean & 53.145 & 49.761 & 50.688 & 52.117 & 51.962 & 52.055 & 50.635 \\
\hline & Std. dev. & 13.573 & 12.017 & 13.273 & 12.756 & 12.357 & 13.159 & 12.424 \\
\hline \multirow[t]{2}{*}{ Active $\mathrm{HH}$ members } & Mean & 2.857 & 3.075 & 3.051 & 2.848 & 2.906 & 2.838 & 3.125 \\
\hline & Std. dev. & 1.454 & 1.447 & 1.487 & 1.412 & 1.418 & 1.424 & 1.469 \\
\hline \multirow[t]{2}{*}{ Classified as poor } & Mean & 0.131 & 0.173 & 0.201 & 0.119 & 0.102 & 0.117 & 0.197 \\
\hline & Std. dev. & 0.338 & 0.379 & 0.401 & 0.324 & 0.303 & 0.321 & 0.398 \\
\hline
\end{tabular}

Source: Authors' own calculations based on VARHS. 
Table 3: Impact of shocks on income and consumption

\begin{tabular}{|c|c|c|c|c|c|c|c|c|}
\hline & $\begin{array}{c}\text { (1) } \\
\text { Total income }\end{array}$ & $\begin{array}{c}\text { (2) } \\
\text { Crops }\end{array}$ & Livestock & $\begin{array}{c}(4) \\
\text { Wage }\end{array}$ & $\begin{array}{l}\text { Share: } \\
\text { HH enterprise }\end{array}$ & $\begin{array}{c}\text { (6) } \\
\text { Transfers } \\
\text { (private) }\end{array}$ & $\begin{array}{c}\text { (7) } \\
\text { Transfers } \\
\text { (public) }\end{array}$ & $\begin{array}{c}(8) \\
\text { Food }\end{array}$ \\
\hline Shock & $\begin{array}{c}-0.061^{\star * *} \\
(0.018)\end{array}$ & $\begin{array}{c}-0.021^{\star * *} \\
(0.006)\end{array}$ & $\begin{array}{c}0.003 \\
(0.004)\end{array}$ & $\begin{array}{l}0.014^{*} \\
(0.008)\end{array}$ & $\begin{array}{l}-0.005 \\
(0.006)\end{array}$ & $\begin{array}{c}-0.002 \\
(0.005)\end{array}$ & $\begin{array}{c}0.009 * * * \\
(0.003)\end{array}$ & $\begin{array}{l}-0.000 \\
(0.019)\end{array}$ \\
\hline Household FE & Yes & Yes & Yes & Yes & Yes & Yes & Yes & Yes \\
\hline Time FE & Yes & Yes & Yes & Yes & Yes & Yes & Yes & Yes \\
\hline Observations & 8,225 & 8,207 & 8,207 & 8,207 & 8,207 & 8,207 & 8,207 & 8,333 \\
\hline R-squared & 0.189 & 0.111 & 0.012 & 0.062 & 0.005 & 0.051 & 0.029 & 0.080 \\
\hline Number of $\mathrm{HHs}$ & 2,124 & 2,120 & 2,120 & 2,120 & 2,120 & 2,120 & 2,120 & 2,125 \\
\hline
\end{tabular}

Note: Robust standard errors clustered at the commune level in parentheses. ${ }^{\star \star \star} p<0.01,{ }^{\star *} p<0.05,{ }^{*} p<0.1$.

Source: Authors' own calculations based on VARHS.

Table 4: Impact of shocks on asset depletion

\begin{tabular}{|c|c|c|c|c|c|c|c|c|c|}
\hline Change in: & $\begin{array}{c}(1) \\
\text { Total assets } \\
\end{array}$ & $\begin{array}{c}(2) \\
\text { Land }\end{array}$ & $\begin{array}{c}(3) \\
\text { Livestock }\end{array}$ & $\begin{array}{c}\text { (4) } \\
\text { Equip (ag) }\end{array}$ & $\begin{array}{c}\text { (5) } \\
\text { Equip (other) }\end{array}$ & $\begin{array}{c}(6) \\
\text { Savings }\end{array}$ & $\begin{array}{c}(7) \\
\text { Crop storage }\end{array}$ & $\begin{array}{c}(8) \\
\text { Durables }\end{array}$ & $\begin{array}{c}(9) \\
\text { Loans }\end{array}$ \\
\hline Shock & $\begin{array}{c}0.097 \\
(0.085)\end{array}$ & $\begin{array}{c}0.294 \\
(0.192)\end{array}$ & $\begin{array}{l}0.446^{\star \star \star} \\
(0.148)\end{array}$ & $\begin{array}{l}0.549 * \star \star \\
(0.173)\end{array}$ & $\begin{array}{c}0.011 \\
(0.115)\end{array}$ & $\begin{array}{l}-0.555^{\star \star} \\
(0.238)\end{array}$ & $\begin{array}{l}-0.103 \\
(0.120)\end{array}$ & $\begin{array}{c}0.033 \\
(0.068)\end{array}$ & $\begin{array}{c}1.019 * \star * \\
(0.252)\end{array}$ \\
\hline Household FE & Yes & Yes & Yes & Yes & Yes & Yes & Yes & Yes & Yes \\
\hline Time FE & Yes & Yes & Yes & Yes & Yes & Yes & Yes & Yes & Yes \\
\hline $\mathrm{HH}$ controls & Yes & Yes & Yes & Yes & Yes & Yes & Yes & Yes & Yes \\
\hline Observations & 6,360 & 6,361 & 6,361 & 6,361 & 6,361 & 6,361 & 6,361 & 6,361 & 6,361 \\
\hline R-squared & 0.021 & 0.010 & 0.010 & 0.027 & 0.333 & 0.023 & 0.010 & 0.388 & 0.019 \\
\hline Number of $\mathrm{HHs}$ & 2,002 & 2,002 & 2,002 & 2,002 & 2,002 & 2,002 & 2,002 & 2,002 & 2,002 \\
\hline
\end{tabular}

Note: Robust standard errors clustered at the commune level in parentheses. ${ }^{\star \star \star} p<0.01,{ }^{\star *} p<0.05,{ }^{*} p<0.1$.

Source: Authors' own calculations based on VARHS. 
We next turn our attention to exploring the impact of past exposure to risk on asset accumulation. The key question is whether households that have been exposed to extreme weather events in the past are more risk averse in terms of asset accumulation. Table 5 relates the level of assets held by households to their exposure to risk in the past, measured as the standard deviation of the threeyear lag of rainfall from the average in the previous six years. ${ }^{7}$ We use the three-year lag to distinguish this variable from the natural shocks indicator, which is based on shocks incurred in the previous two years. We also include the lagged rainfall level, which will control for the fact that a certain level of rain is required for rice production. ${ }^{8}$ It is deviations from expected rainfall levels that are detrimental and can be considered a form of uninsurable risk that could cause farmers to take risk-mitigating actions.

Table 5: Impact of risk on asset accumulation

\begin{tabular}{|c|c|c|c|}
\hline & $\begin{array}{c}(1) \\
\text { Total assets }\end{array}$ & $\begin{array}{c}(2) \\
\text { Productive asset share }\end{array}$ & $\begin{array}{c}\text { (3) } \\
\text { Unproductive asset share }\end{array}$ \\
\hline Shock & $\begin{array}{c}0.083 \\
(0.051)\end{array}$ & $\begin{array}{l}0.042^{\star \star \star} \\
(0.009)\end{array}$ & $\begin{array}{l}-0.042^{\star \star \star} \\
(0.009)\end{array}$ \\
\hline Past dev. rainfall & $\begin{array}{l}-2.123^{\star \star \star} \\
(0.276)\end{array}$ & $\begin{array}{l}-0.321^{\star \star *} \\
(0.056)\end{array}$ & $\begin{array}{l}0.321^{* * *} \\
(0.056)\end{array}$ \\
\hline Past mean rainfall & $\begin{array}{c}0.190 \\
(0.198)\end{array}$ & $\begin{array}{c}0.024 \\
(0.038)\end{array}$ & $\begin{array}{l}-0.024 \\
(0.038)\end{array}$ \\
\hline Household FE & Yes & Yes & Yes \\
\hline Time FE & Yes & Yes & Yes \\
\hline $\mathrm{HH}$ controls & Yes & Yes & Yes \\
\hline Observations & 7,735 & 7,735 & 7,735 \\
\hline R-squared & 0.132 & 0.025 & 0.025 \\
\hline Number of $\mathrm{HHs}$ & 1,953 & 1,953 & 1,953 \\
\hline
\end{tabular}

Note: Robust standard errors clustered at the commune level in parentheses. ${ }^{\star \star \star} p<0.01,{ }^{\star \star} p<0.05,{ }^{*} p<0.1$.

Source: Authors' own calculations based on VARHS.

Table 6: Impact of risk on asset accumulation (details)

\begin{tabular}{|c|c|c|c|c|c|c|c|c|}
\hline & (1) & (2) & (3) & (4) & (4) & (5) & (6) & (7) \\
\hline Share & Land & Livestock & $\begin{array}{l}\text { Equip } \\
\text { (ag.) }\end{array}$ & $\begin{array}{l}\text { Equip } \\
\text { (other) }\end{array}$ & Savings & $\begin{array}{l}\text { Crop } \\
\text { store }\end{array}$ & Durables & Loans \\
\hline Shock & $\begin{array}{l}0.032^{\star *} \\
(0.014)\end{array}$ & $\begin{array}{l}0.015^{\star *} \\
(0.006)\end{array}$ & $\begin{array}{c}0.000 \\
(0.001)\end{array}$ & $\begin{array}{l}-0.004 \\
(0.005)\end{array}$ & $\begin{array}{c}-0.031^{\star * \star} \\
(0.006)\end{array}$ & $\begin{array}{c}-0.010^{\star *} \\
(0.004)\end{array}$ & $\begin{array}{l}-0.001 \\
(0.003)\end{array}$ & $\begin{array}{c}0.683^{\star * *} \\
(0.148)\end{array}$ \\
\hline Past dev. rainfall & $\begin{array}{c}-0.589 * \star * * \\
(0.086)\end{array}$ & $\begin{array}{l}0.106^{\star *} \\
(0.042)\end{array}$ & $\begin{array}{c}0.007 \\
(0.013)\end{array}$ & $\begin{array}{l}0.151 * * * \\
(0.030)\end{array}$ & $\begin{array}{l}0.092^{\star *} \\
(0.044)\end{array}$ & $\begin{array}{c}0.107^{* * *} \\
(0.024)\end{array}$ & $\begin{array}{c}0.122^{\star * *} \\
(0.020)\end{array}$ & $\begin{array}{c}1.341 \\
(1.017)\end{array}$ \\
\hline Past mean rainfall & $\begin{array}{c}0.022 \\
(0.054)\end{array}$ & $\begin{array}{c}-0.045 \\
(0.031)\end{array}$ & $\begin{array}{c}0.021^{* * *} \\
(0.006)\end{array}$ & $\begin{array}{c}0.024 \\
(0.018)\end{array}$ & $\begin{array}{l}-0.049^{\star} \\
(0.026)\end{array}$ & $\begin{array}{c}0.015 \\
(0.017)\end{array}$ & $\begin{array}{c}0.010 \\
(0.010)\end{array}$ & $\begin{array}{l}-0.630 \\
(0.495)\end{array}$ \\
\hline Household FE & Yes & Yes & Yes & Yes & Yes & Yes & Yes & Yes \\
\hline Time FE & Yes & Yes & Yes & Yes & Yes & Yes & Yes & Yes \\
\hline $\mathrm{HH}$ controls & Yes & Yes & Yes & Yes & Yes & Yes & Yes & Yes \\
\hline Observations & 7,735 & 7,735 & 7,735 & 7,735 & 7,735 & 7,735 & 7,735 & 7,735 \\
\hline R-squared & 0.081 & 0.038 & 0.027 & 0.152 & 0.036 & 0.069 & 0.110 & 0.042 \\
\hline Number of $\mathrm{HHs}$ & 1,953 & 1,953 & 1,953 & 1,953 & 1,953 & 1,953 & 1,953 & 1,953 \\
\hline
\end{tabular}

Note: Robust standard errors clustered at the commune level in parentheses. ${ }^{\star \star *} p<0.01,{ }^{\star *} p<0.05,{ }^{*} p<0.1$.

Source: Authors' own calculations based on VARHS.

\footnotetext{
${ }^{7}$ Our findings are robust to the choice of a lag length of three or four and an average of five to six years.

${ }^{8}$ Rice production requires that the crop is submerged in water from planting through to harvest. This is normally controlled through irrigation systems.
} 
As revealed in Table 5, households exposed to large deviations in rainfall in the past accumulate less assets, and a greater share of their assets is unproductive. As discussed above, households that are exposed to flood risk are less likely to invest in inputs and other productive assets that have a significant downside risk. The perceived probability of flooding is higher for these households given their past exposure to floods and so they run the risk of losing any investment made should a flood occur and their crop fail (Emerick et al. 2016). They are therefore more likely to invest their money in other types of assets that they can draw down in the event of a shock.

We explore the different asset categories in Table 6. Households exposed to more rainfall risk hold less of their assets in the form of land and more in the form of livestock (a buffer stock), liquid savings, crop stores, and durable goods. This is consistent with the idea that risk negatively impacts on the productive investments of households with more assets held in liquid form. The one exception is non-agricultural equipment which includes transport vehicles and personal computers. While they could be considered productive assets, they could also be considered liquid assets that could be sold in times of crisis.

In Table 7, we investigate the extent to which risk has negative consequences for contemporaneous income and food expenditure. We find in column (1) that households exposed to risk in the past have much lower incomes than other households, even when shocks in the previous two years are controlled for. This could be due to a number of factors but could indeed be linked with the decision of farmers that are risk exposed to invest in unproductive assets. It could also be due to previous losses to income as a result of past shocks, but the inclusion of household fixed effects makes this unlikely. Exposure to risk, does not translate into lower levels of food expenditure, suggesting again that households manage to develop coping strategies to smooth consumption.

Table 7 also explores the proportion of income from different sources for risk-exposed households. Households exposed to past risks earn a significantly greater proportion of their income from crops compared with other households. This suggests that these households are particularly vulnerable given that they are investing away from productive assets that could improve their agricultural productivity, while at the same time this is their primary source of income.

In the final step of our analysis, we explore the extent to which households that have adjusted their asset portfolio in response to past exposure to risk are better able to cope in the event of an income shock. In other words, do they experience less of an income loss and do they have to deplete fewer of their assets? We explore this possibility by including an interaction term between the risk exposure variable and the occurrence of a natural shock in the previous two-year period. The results for income are presented in column (8) of Table 7. The statistical insignificance of the interaction term suggests that households with long-term risk exposure fare no better (or worse) than those that have not previously been exposed to risk in the event of a natural shock on their income levels.

In Table 8, we extend the analysis to consider different types of coping mechanisms in the form of asset depletion and access to credit. Recall from Table 4, that in the face of natural shocks households deplete their stock of savings and rely on loans to cope. There is no evidence in Table 8 that households that have had previous risk exposure do this to any less of an extent. The only statistically significant interaction term is on the change in consumption durables. We find that households that have previously been exposed to risk increase their stock of consumption durables 
if a natural shock is realized. ${ }^{9}$ This suggests that they step up efforts to buffer against future income losses when further weather-related shocks are realized.

Overall, our results suggest that households that are exposed to risk invest in unproductive assets to avoid the downside risk associated with exposure to flooding even though a greater proportion of their income comes from crops compared with other households. This translates into significantly lower overall household income levels. Ultimately, the investment in these 'buffer' assets does not appear to pay off once actual risks are realized and so they are hit in more or less a similar way to other households that did not engage in such risk-mitigation strategies.

\footnotetext{
${ }^{9}$ The joint effect is statistically significant at the 1 per cent significance level.
} 
Table 7: Impact of risk on income and consumption

\begin{tabular}{|c|c|c|c|c|c|c|c|c|}
\hline & (1) & (2) & (3) & (4) & (5) & (6) & (7) & (8) \\
\hline & Total income & Crops & Livestock & Wage & $\begin{array}{l}\mathrm{e}: \\
\mathrm{HH} \text { enterprise }\end{array}$ & $\begin{array}{c}\text { Transfers } \\
\text { (private) }\end{array}$ & $\begin{array}{c}\text { Transfers } \\
\text { (public) }\end{array}$ & Total Income \\
\hline Shock $x$ past dev. rain & & & & & & & & $\begin{array}{c}0.115 \\
(0.124)\end{array}$ \\
\hline Shock & $\begin{array}{c}-0.053^{\star \star \star} \\
(0.018)\end{array}$ & $\begin{array}{c}-0.020 \star \star \star * \\
(0.006)\end{array}$ & $\begin{array}{c}0.004 \\
(0.004)\end{array}$ & $\begin{array}{l}0.014^{*} \\
(0.008)\end{array}$ & $\begin{array}{l}-0.006 \\
(0.006)\end{array}$ & $\begin{array}{l}-0.003 \\
(0.005)\end{array}$ & $\begin{array}{l}0.009 * \star \star \\
(0.003)\end{array}$ & $\begin{array}{c}-0.052^{\star \star \star} \\
(0.018)\end{array}$ \\
\hline Past dev. rainfall & $\begin{array}{c}-0.652^{* * *} \\
(0.120)\end{array}$ & $\begin{array}{l}0.072^{\star *} \\
(0.035)\end{array}$ & $\begin{array}{c}0.014 \\
(0.029)\end{array}$ & $\begin{array}{l}-0.009 \\
(0.045)\end{array}$ & $\begin{array}{l}-0.004 \\
(0.025)\end{array}$ & $\begin{array}{l}-0.014 \\
(0.031)\end{array}$ & $\begin{array}{l}-0.017 \\
(0.019)\end{array}$ & $\begin{array}{c}-0.667^{\star \star *} \\
(0.121)\end{array}$ \\
\hline Past mean rainfall & $\begin{array}{l}-0.006 \\
(0.072)\end{array}$ & $\begin{array}{c}0.015 \\
(0.027)\end{array}$ & $\begin{array}{l}-0.005 \\
(0.018)\end{array}$ & $\begin{array}{c}0.010 \\
(0.033)\end{array}$ & $\begin{array}{c}0.015 \\
(0.018)\end{array}$ & $\begin{array}{l}-0.036^{\star *} \\
(0.017)\end{array}$ & $\begin{array}{c}0.003 \\
(0.011)\end{array}$ & $\begin{array}{l}-0.020 \\
(0.072)\end{array}$ \\
\hline Household FE & Yes & Yes & Yes & Yes & Yes & Yes & Yes & Yes \\
\hline Time FE & Yes & Yes & Yes & Yes & Yes & Yes & Yes & Yes \\
\hline $\mathrm{HH}$ controls & Yes & Yes & Yes & Yes & Yes & Yes & Yes & Yes \\
\hline Observations & 7,644 & 7,627 & 7,627 & 7,627 & 7,627 & 7,627 & 7,627 & 7,644 \\
\hline R-squared & 0.192 & 0.114 & 0.012 & 0.061 & 0.005 & 0.052 & 0.031 & 0.192 \\
\hline Number of $\mathrm{HHs}$ & 1,952 & 1,948 & 1,948 & 1,948 & 1,948 & 1,948 & 1,948 & 1,952 \\
\hline
\end{tabular}

Note: Robust standard errors clustered at the commune level in parentheses. ${ }^{\star \star \star} p<0.01,{ }^{\star \star} p<0.05,{ }^{*} p<0.1$.

Source: Authors' own calculations based on VARHS. 
Table 8: Exposure to risk and coping mechanisms-asset depletion

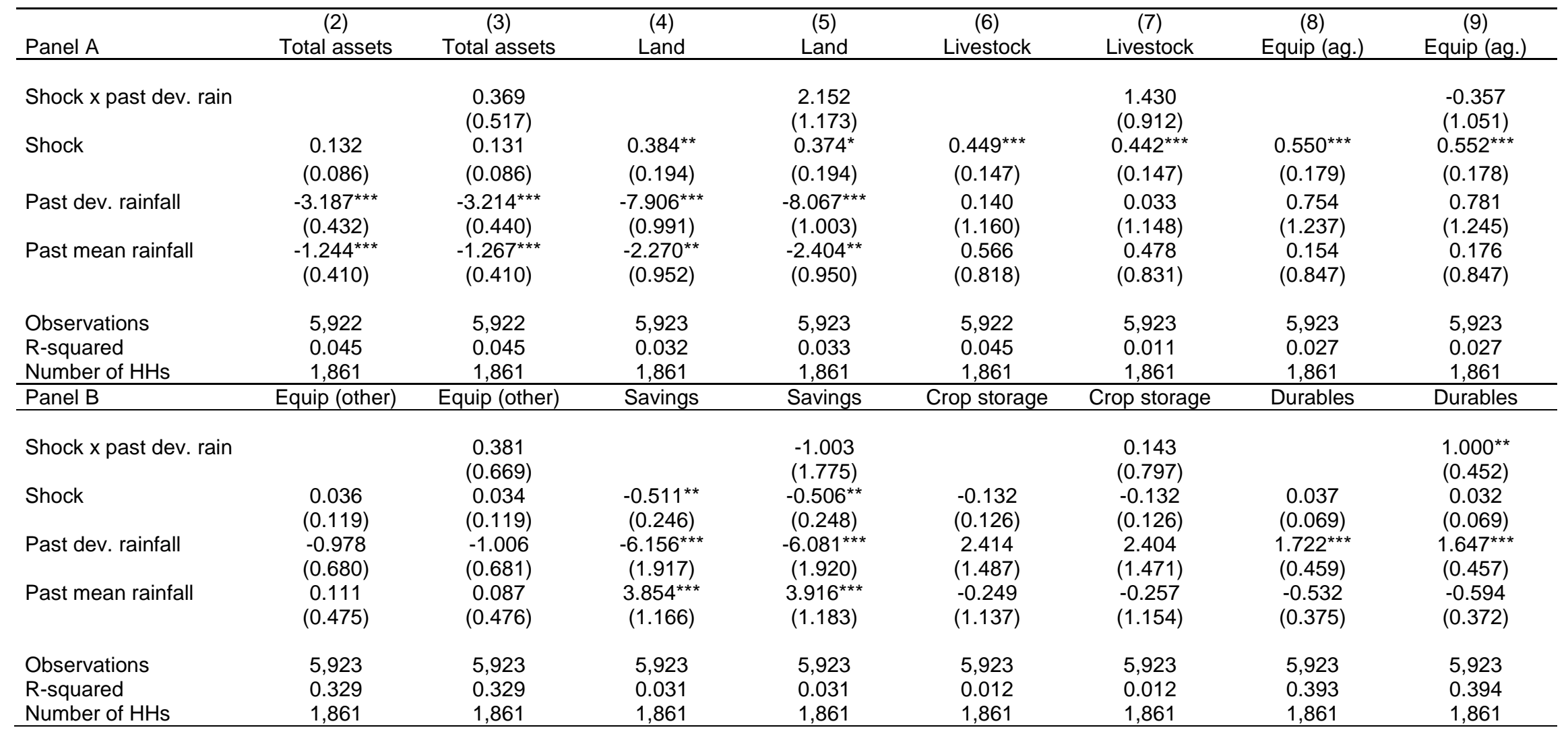

Note: Robust standard errors clustered at the commune level in parentheses. ${ }^{\star * \star} p<0.01,{ }^{\star *} p<0.05,{ }^{*} p<0.1$. Each specification includes household and time fixed effects and time-varying control variables. We exclude the value of loans from the table as the results are not statistically significant for any of the risk variables or the interaction.

Source: Authors' own calculations based on VARHS. 
This paper explored the impact that exposure to uninsured weather-related risk has on the production decisions of rice farmers, in particular in relation to the accumulation of assets. This included examining the impact of actual realized shocks on household income and food consumption and an exploration of the risk-coping mechanisms of households in the aftermath of shocks. The focus of the paper was on the interaction between past exposure to risk and riskmitigation strategies and the realization of shocks to ascertain the extent to which these strategies serve as a buffer and so pay off by protecting households against income losses.

Using a rich household level panel dataset from Viet Nam for the 2008-16 period and matched data on rainfall levels for the 2000-14 period, we addressed these issues in the context of riskexposed rice-producing farmers in a vulnerable setting. We found that households suffer income losses when they experience shocks, but not losses in consumption, and buffer these losses through depleting savings and taking out loans. There is some evidence to suggest that they also re-invest in farm assets and livestock after exposure to a shock.

It emerged that past risk exposure leads to lower levels of investment in assets in general and a lower level of productive assets in particular. This is consistent with other findings from developing country contexts which show that in the face of uninsured risk households divert resources away from risky income-producing assets and invest more in the form of precautionary savings. Ultimately, this leads to lower income levels for those farmers who rely more on crop income than other households.

We also found that these investment strategies do not help to buffer these households against future natural shocks. When shocks are realized, they experience the same drop in income as other households and are no different in their need to deplete the stock of savings and take out loans to cope with the shock. We also found that they invest even more in unproductive durable goods in the aftermath of a shock, suggesting that continued exposure to risk shifts the asset portfolio away from income-generating assets to an even greater extent.

A key policy implication of these results is that measures to eliminate the downside risk associated with agricultural production in uncertain climates could be transformative in improving the productivity of rural farmers, allocating resources to more productive uses, and improving welfare. A number of recent studies have found evidence supporting policies that offer rainfall insurance to vulnerable farmers to protect against risk (Dercon et al. 2014; Karlan et al. 2014). ${ }^{10}$ The difficulties, however, in rolling out agricultural insurance, both in terms of supply-side and demand-side constraints, should not be underestimated. Carter et al. (2016), Cole et al. (2013), and Giné et al. (2008) all highlight the difficulties in developing agricultural insurance products that are both sustainable and affordable. Given the potential benefits of such products, future research is needed in this area. In addition, other innovative mechanisms for eliminating downside risk are worth considering. For example, Emerick et al. (2016) demonstrate the effectiveness of new technologies that eliminate downside risk in changing the input choices of farmers, leading to higher productivity levels. Innovations of this kind are promising, particularly in rural settings such

\footnotetext{
${ }^{10}$ In addition, see Cole and Xiong (2015) for an overview of the literature on the impact of agricultural insurance on investment decisions and its role in smoothing income and consumption.
} 
as that studied in our paper, where agriculture remains an important sector, and vulnerability to climate change and increasing weather variability are significant challenges.

\section{References}

Alderman, H., and C.H. Paxson (1992). 'Do the Poor Insure? A Synthesis of the Literature on Risk and Consumption in Developing Countries'. Policy Research Working Papers WPS 1008, Agricultural Policies. Washington, DC: World Bank.

Carter, M., A. de Janvry, E. Sadoulet, and A. Sarris (2016). 'Index Insurance for Developing Country Agriculture: A Reassessment'. Annual Review of Resource Economics, 9: 421-38.

Cole, S., X. Giné, J. Tobacman, P. Topalova, R. Townsend, and J. Vickery (2013). 'Barriers to Household Risk Management: Evidence from India'. American Economic Journal: Applied Economics, 5(1): 104-35.

Cole, S., X. Giné, J. Tobacman, P. Topalova, R. Townsend, and J. Vickery (2017). 'How Does Risk Management Influence Production Decisions? Evidence from a Field Experiment'. The Review of Financial Studies, 30(6): 1935-70.

Cole, S., and W. Xiong (2015). 'Agricultural Insurance and Economic Development'. Annual Review of Economics, 9: 235-62.

Deaton, A. (1991). 'Savings and Liquidity Constraints'. Econometrica, 59(5): 1221-48.

Deaton, A. (1992). 'Household Saving in LDCs: Credit Markets, Insurance and Welfare'. Scandinavian Journal of Economics, 94(2): 253-73.

Dercon, S. (2002). 'Income Risk, Coping Strategies and Safety Nets'. World Bank Research Observer, 17(2): 141-66.

Dercon, S., R.V. Hill, D. Clarke, I. Outes-Leon, and A. Seyoum Taffesse (2014). 'Offering Rainfall Insurance to Informal Insurance Groups: Evidence from a Field Experiment in Ethiopia'. Journal of Development Economics, 206(C): 132-43.

Elabed, G., and M. Carter (2014). 'Ex Ante Impacts of Agricultural Insurance: Evidence from a Field Experiment in Mali'. Available at: https://arefiles.ucdavis.edu/uploads/filer_public/2014/04/25/elabedimpact_evaluation_0422_vdraft2_1.pdf (accessed November 2017).

Emerick, K., A. de Janvry, E. Sadoulet, and M. Dar (2016). 'Technological Innovations, Downside Risk, and the Modernization of Agriculture'. American Economic Review, 106(6): 1537-61.

Fafchamps, M., K. Czukas, and C. Udry (1998). 'Drought and Saving in West-Africa: Are Livestock a Buffer Stock'. Journal of Development Economics, 55(2): 273-305.

Giné, X., R. Townsend, and J. Vickery (2008). 'Patterns of Rainfall Insurance Participation in Rural India'. World Bank Economic Review, 22(3): 539-66.

Gloede, O. (2015). 'Shocks, Individual Risk Attitude, and Vulnerability to Poverty among Rural Households in Thailand and Vietnam'. World Development, 71: 54-78.

Jensen, N.D., C.B. Barrett, and A.G. Mude (2017). 'Cash Transfers and Index Insurance: A Comparative Impact Analysis from Northern Kenya'. Journal of Development Economics, 129: 14 28.

Karlan, D., R. Darko Osei, I. Osie-Akoto, and C. Udry (2014). 'Agricultural Decisions after Relaxing Credit and Risk Constraints’. Quarterly Journal of Economics, 129(2): 597-652. 
Morduch, J. (1995). 'Income Smoothing and Consumption Smoothing'. Journal of Economic Perspectives, 9(3): 103-14.

Morduch, J. (2004). 'Consumption Smoothing Across Space: Tests for Village-level Responses to Risk'. In S. Dercon (ed.), Insurance against Poverty. New York, NY: Oxford University Press.

Rosenzweig, M., and H.P. Binswanger (1993). 'Wealth, Weather Risk and the Composition and Profitability of Agricultural Investments'. The Economic Journal, 103(416): 56-78.

Rosenzweig, M., and K. Wolpin (1993). 'Credit Market Constraints, Consumption Smoothing, and the Accumulation of Durable Production Assets in Low-income Countries: Investment in Bullocks in India'. Journal of Political Economy, 101(2): 223-44.

Townsend, R. (1994). 'Risk and Insurance in Village India'. Econometrica, 62(3): 539-91.

Udry, C. (1994). 'Risk and Insurance in a Rural Credit Market: An Empirical Investigation of Northern Nigeria'. Review of Economic Studies, 61(3): 495-526.

Wainwright, F., and C. Newman (2011). 'Income Shocks and Household Risk Coping Strategies: Evidence from rural Vietnam'. IIIS Discussion Paper 358. Dublin: Institute for International Integration Studies.

Willmott, C.J., and K. Matsuura (2001). 'Terrestrial Air Temperature and Precipitation: Monthly and Annual Time Series (1950-1999)'. Available at: http://climate.geog.udel.edu/ $\sim$ climate/html_pages/README.ghcn_ts2.html (accessed on 28 September 2018).

World Bank (2011). Climate Risk and Adaptation Country Profile. World Bank: Washington.

Zeldes, S. (1989). 'Optimal Consumption with Stochastic Income: Deviations from Certainty Equivalence'. Quarterly Journal of Economics, 104(2): 275-98. 


\section{Appendix}

Table A1: Description of variables

\begin{tabular}{|c|c|}
\hline Name & Description \\
\hline \multicolumn{2}{|l|}{ Risk and shocks: } \\
\hline Shock & $=1$ if household exposed to a natural shock and zero otherwise \\
\hline Past dev. rainfall & Standard deviation of 3-year lag rainfall level from 6-year average \\
\hline Past mean rainfall & Log of 3-year lag of average rainfall \\
\hline \multicolumn{2}{|l|}{ Outcomes: } \\
\hline Total income (log) & Log of total household income \\
\hline Share crops & Share of income from crops \\
\hline Share livestock & Share of income from livestock \\
\hline Share other ag. & Share of income from other agricultural enterprises \\
\hline Share wage & Share of income from a wage \\
\hline Share $\mathrm{HH}$ enterprise & Share of income from household enterprises \\
\hline Share rent & Share of income from renting out land or other assets \\
\hline Share private transfers & Share of income from private transfers \\
\hline Share public transfers & Share of income from public transfers \\
\hline Food expenditure (log) & Log of household food expenditure \\
\hline Total assets (log) & Log of total value of assets \\
\hline Share productive & Share of assets that are productive \\
\hline Share unproductive & Share of assets that are unproductive \\
\hline Share land & Share of assets in land (productive) \\
\hline Share livestock & Share of assets in livestock (productive) \\
\hline Share equip (ag.) & Share of assets in agricultural equipment (productive) \\
\hline Share equip (other) & Share of assets in other equipment (productive) \\
\hline Share savings & Share of assets in liquid savings (unproductive) \\
\hline Share crop storage & Share of assets in crop storage (unproductive) \\
\hline Share durables & Share of assets in consumption durables (unproductive) \\
\hline Total loans (log) & Log of total value of loans \\
\hline \multicolumn{2}{|l|}{ Controls } \\
\hline Education per capita & Average years of education per capita in the households \\
\hline Household size & Number of adults and children in the household \\
\hline $\mathrm{Sex} \mathrm{HoH}$ & $=1$ if household head is male and zero otherwise \\
\hline Married $\mathrm{HoH}$ & $=1$ if household head is married and zero otherwise \\
\hline Age $\mathrm{HoH}$ & Age of head of household \\
\hline Active $\mathrm{HH}$ members & Number of household members earning an income \\
\hline Classified as poor & $=1$ if classified as poor for the receipt of state benefits and zero otherwise \\
\hline
\end{tabular}

Source: Authors' own calculations based on VARHS. 
Table A2: Summary statistics for income and food expenditure

\begin{tabular}{|c|c|c|c|c|c|c|}
\hline & & $\begin{array}{c}2008 \\
n=1,491\end{array}$ & $\begin{array}{c}2010 \\
\mathrm{n}=1,437\end{array}$ & $\begin{array}{c}2012 \\
n=1,682\end{array}$ & $\begin{array}{c}2014 \\
n=1,623\end{array}$ & $\begin{array}{c}2016 \\
n=1,429 \\
\end{array}$ \\
\hline \multirow[t]{2}{*}{ Total income (log) } & Mean & 10.653 & 10.776 & 10.921 & 11.079 & 11.138 \\
\hline & Std. dev. & 0.802 & 0.800 & 0.769 & 0.779 & 0.859 \\
\hline \multirow[t]{2}{*}{ Share crops } & Mean & 0.341 & 0.254 & 0.237 & 0.215 & 0.218 \\
\hline & Std. dev. & 0.263 & 0.232 & 0.241 & 0.230 & 0.231 \\
\hline \multirow[t]{2}{*}{ Share livestock } & Mean & 0.088 & 0.092 & 0.093 & 0.110 & 0.086 \\
\hline & Std. dev. & 0.134 & 0.134 & 0.153 & 0.167 & 0.160 \\
\hline \multirow[t]{2}{*}{ Share other ag. } & Mean & 0.045 & 0.055 & 0.042 & 0.039 & 0.026 \\
\hline & Std. dev. & 0.093 & 0.105 & 0.098 & 0.090 & 0.066 \\
\hline \multirow[t]{2}{*}{ Share wage } & Mean & 0.313 & 0.336 & 0.363 & 0.386 & 0.410 \\
\hline & Std. dev. & 0.321 & 0.332 & 0.335 & 0.340 & 0.350 \\
\hline \multirow[t]{2}{*}{ Share $\mathrm{HH}$ enterprise } & Mean & 0.099 & 0.096 & 0.105 & 0.101 & 0.106 \\
\hline & Std. dev. & 0.217 & 0.216 & 0.237 & 0.235 & 0.249 \\
\hline \multirow[t]{2}{*}{ Share rent } & Mean & 0.001 & 0.002 & 0.002 & 0.002 & 0.001 \\
\hline & Std. dev. & 0.016 & 0.013 & 0.028 & 0.023 & 0.013 \\
\hline \multirow[t]{2}{*}{ Share private transfers } & Mean & 0.059 & 0.093 & 0.085 & 0.080 & 0.077 \\
\hline & Std. dev. & 0.150 & 0.178 & 0.175 & 0.164 & 0.157 \\
\hline \multirow[t]{2}{*}{ Share public transfers } & Mean & 0.051 & 0.067 & 0.060 & 0.060 & 0.066 \\
\hline & Std. dev. & 0.135 & 0.150 & 0.144 & 0.139 & 0.133 \\
\hline \multirow[t]{2}{*}{ Food expenditure (log) } & Mean & 7.233 & 7.217 & 7.279 & 7.158 & 7.165 \\
\hline & Std. dev. & 0.910 & 0.671 & 0.729 & 0.697 & 0.770 \\
\hline
\end{tabular}

Source: Authors' own calculations based on VARHS.

Table A3: Summary statistics for assets

\begin{tabular}{llccccc}
\hline & & 2008 & 2010 & 2012 & 2014 & 2016 \\
& & $\mathrm{n}=1,506$ & $\mathrm{n}=1,450$ & $\mathrm{n}=1,694$ & $\mathrm{n}=1,640$ & $\mathrm{n}=1,447$ \\
\hline Total assets (log) & Mean & 11.076 & 11.471 & 11.893 & 12.174 & 12.043 \\
& Std. dev. & 1.440 & 1.567 & 1.589 & 1.566 & 1.695 \\
Share productive & Mean & 0.706 & 0.716 & 0.753 & 0.774 & 0.752 \\
& Std. dev. & 0.260 & 0.256 & 0.264 & 0.257 & 0.315 \\
Share unproductive & Mean & 0.294 & 0.284 & 0.247 & 0.226 & 0.248 \\
& Std. dev. & 0.260 & 0.256 & 0.264 & 0.257 & 0.315 \\
Share land & Mean & 0.310 & 0.364 & 0.477 & 0.506 & 0.530 \\
Share livestock & Std. dev. & 0.371 & 0.403 & 0.419 & 0.423 & 0.434 \\
Share equip (ag.) & Mean & 0.235 & 0.206 & 0.161 & 0.170 & 0.217 \\
& Std. dev. & 0.260 & 0.244 & 0.239 & 0.247 & 0.304 \\
Share equip (other) & Mean & 0.015 & 0.019 & 0.012 & 0.008 & 0.001 \\
Share savings & Std. dev. & 0.066 & 0.069 & 0.047 & 0.036 & 0.004 \\
& Mean & 0.149 & 0.132 & 0.108 & 0.095 & 0.003 \\
Share crop storage & Std. dev. & 0.185 & 0.165 & 0.149 & 0.133 & 0.013 \\
& Mean & 0.093 & 0.142 & 0.136 & 0.131 & 0.178 \\
Share durables & Std. dev. & 0.173 & 0.200 & 0.198 & 0.189 & 0.268 \\
& Mean & 0.121 & 0.077 & 0.059 & 0.047 & 0.065 \\
Total loans (log) & Std. dev. & 0.153 & 0.120 & 0.102 & 0.085 & 0.136 \\
& Mean & 0.079 & 0.065 & 0.051 & 0.048 & 0.005 \\
& Std. dev. & 0.104 & 0.093 & 0.086 & 0.084 & 0.020 \\
& Mean & 4.654 & 5.036 & 4.196 & 3.818 & 3.189 \\
\hline
\end{tabular}

Source: Authors' own calculations based on VARHS. 
Table A4: Summary statistics for control variables

\begin{tabular}{llccccc}
\hline & & 2008 & 2010 & 2012 & 2014 & 2016 \\
& & $\mathrm{n}=1,506$ & $\mathrm{n}=1,450$ & $\mathrm{n}=1,694$ & $\mathrm{n}=1,640$ & $\mathrm{n}=1,447$ \\
\hline Education per capita & Mean & 8.147 & 8.218 & 8.462 & 8.666 & 9.022 \\
& Std. dev. & 2.833 & 2.758 & 2.633 & 2.612 & 2.366 \\
Household size & Mean & 4.749 & 4.532 & 4.417 & 4.402 & 4.391 \\
Sex HoH & Std. dev. & 1.740 & 1.710 & 1.664 & 1.662 & 1.682 \\
& Mean & 0.822 & 0.826 & 0.827 & 0.816 & 0.816 \\
Married HoH & Std. dev. & 0.383 & 0.380 & 0.378 & 0.387 & 0.387 \\
\multirow{3}{*}{ Age HoH } & Mean & 0.841 & 0.840 & 0.837 & 0.837 & 0.831 \\
& Std. dev. & 0.366 & 0.367 & 0.369 & 0.369 & 0.375 \\
Active HH members & Mean & 51.025 & 52.066 & 50.345 & 51.535 & 52.727 \\
& Std. dev. & 12.817 & 12.419 & 13.236 & 12.998 & 12.789 \\
Classified as poor & Mean & 3.147 & 3.018 & 2.907 & 2.873 & 2.820 \\
& Std. dev. & 1.490 & 1.464 & 1.424 & 1.416 & 1.434 \\
& Mean & 0.212 & 0.140 & 0.199 & 0.135 & 0.046 \\
\hline
\end{tabular}

Source: Authors' own calculations based on VARHS. 